\title{
War Resistance and Resisters: The Myth of Protest and Popular Dissent against the Vietnam War in Australia and Canada
}

\section{Piper Rodd ${ }^{1}$}

\section{Introduction}

At the height of the Cold War, tensions over ideological and territorial ascendency escalated in South-East Asia. The West, fearing that the expansive designs of Ho Chi Min presaged only the further spread of communism in the region, involved itself in a messy, costly, and ultimately unpopular war. Australian military support for the war swiftly followed the American commitment even as Britain remained aloof. War, once again, was foregrounded in the lives of another generation of Australians.

Canadians of the same generation (those who would be eligible to be co-opted and conscripted into war) distanced themselves from a perceived eagerness to go to war as their country assumed the mantle of the nation of peaceful co-existence.

In this article I examine the era in which the Vietnam War was fought, studying the experiences of war, protest, and the forms of resistance to war taken by Canada and Australia, two countries that responded differently to the American call to fight. By resisting the American urging to join the war, Canada made a decisive break with the tradition of participation in wars fought by the Anglosphere, a tradition that had seen Canada consistently supporting their American neighbours and the British Empire in successive global wars. More commonly known of this era, Canada accepted thousands of Americans of draft age as landed immigrants.

Successive Liberal governments through the 1960s and 1970s, led by social reformers Lester B. Pearson and Pierre Trudeau, heralded progressive reform for a prosperous and increasingly self-confident Canadian society. Yet Canada was

\footnotetext{
${ }^{1}$ I want to express my appreciation to the editor of the journal as well as the two anonymous peer reviewers for their comments and suggestions.
} 
quietly complicit in the war despite not committing its citizens to the battlefront. As the Pentagon Papers would reveal, Prime Minister Pearson, and his successor Trudeau, were engaged in diplomatic action aimed at supporting the Americans in waging their war against communism. ${ }^{2}$ The Canadian economy was also intimately tied up with the war through its military-industrial complex and related manufacturers who, while not directly involved with war-related industry, profited from the war by providing miscellaneous services to the American army. As McKay and Swift put it, 'throughout the Vietnam War, Canada proclaimed peace and abetted war.'3

Australia, conversely, perpetuated its tradition of war, entering the conflict early and remaining alongside the Americans for over a decade as the bloody and increasingly controversial ideological battle drew on. While Australians fought and, for the most part, supported the war, this era carries a significant weight of cultural, social and political mythology, positioning war resistance front-and-centre in Australian society. Anti-war protest, popular dissent, and radical politics are popularly represented as overwhelmingly characteristic of this period in Western history. However, as I argue in this article, the national mythology surrounding this era that represents it as a time of singular social activism and popular dissent from the orthodoxy of war is complicit in distorting the nuance of the social and political meaning for both Canada and Australia. While the final years of the Vietnam conflict did engender a significant popular disavowal of war, this resistance took many years to achieve and was, even then, far from universal or dominantly paradigmatic.

The significance of this article lies in part in its comparative approach to the study of this history. Through examining the myriad responses to the war and

\footnotetext{
${ }^{2}$ Ian McKay and Jamie Swift, Warrior Nation: Rebranding Canada in an Age of Anxiety (Toronto: Between the Lines, 2012), 159.

${ }^{3}$ Ibid., 154.
} 
resistance in the developments of Canada and Australia, cultural and political patterns and their disjunctions become evident. A sweeping view of the histories of both Canada and Australia exposes a habit of invoking war in the construction of a national consciousness in nations that are relatively young members of the new world. Wars have indelibly shaped the political structures and cultural identities of Canada and Australia. Significantly though, a key strand of the national stories of both countries represents them as domestically peaceful with laudable nationbuilding pasts formed in the absence of foundational violence. Neither fought a civil war. While participation in foreign war has been frequent, and crucial in the cultural formation of identities, the reputations of both Canada and Australia are renowned for their relatively brief national histories through which statehood was achieved by comparatively peaceful means.

\section{War and National Mythologies}

For these countries, the frontier wars fought by the colonial invaders against the Indigenous peoples in the process of wrenching their lands from them are not, according to national mythology, officially episodes of war. Canada has been nicknamed "the peaceable kingdom" due, in the first instance, to the absence of a violent or sustained civil war or of any continuing and pronounced episodes of popular dissent in the process of constructing the nation. ${ }^{4}$ Australians point to the peaceful union achieved by Federation in 1901. The idea that Australian settlement was a peaceful enterprise has a long tradition. It also has a strong historical connection of being linked with external war. Henry Reynolds describes, for instance,

\footnotetext{
${ }^{4}$ Judy Torrance, Public Violence in Canada, 1867-1982, (Montreal: McGill-Queen's Press, 1986), 100.
} 
while the tales of bravery and national vigour were represented as emblematic of the wars fought overseas, the battles waged on Australian soil were disregarded as unhealthy fantasy, propagated by those who sought only to deceive and divide the nation. ${ }^{5}$ War has been commonly venerated in both countries' mythologies, if only those fought on foreign soil.

While protest, acts of civil disobedience and war resistance were evident, indeed significant, during this period, so too was adherence to conservative values that included support for a war that promised to end the creep of communism which so frightened the mainstream for the duration of the Cold War. Christina Twomey, ${ }^{6}$ for instance, points out that national service was popularly supported in Australia throughout the war, in part precisely because of the widespread perceived threat of the communist hordes as well as the belief that service instilled laudable values of discipline and obedience in young men. This era does, however, represent something of a turning point in the evolution of both societies in terms of their cultivation of nationalism. War, and resistance to it, was significant to this cultural decisiveness as both countries emerged from this era feeling stronger and more secure in their own sense of national self. The comparison of the two countries' experiences suggests something important. It is in this era in which the biggest apparent difference existed in their respective historical experiences of war - one country going to war while the other abstained from it - and its cultural resistance. However, perhaps the contrasts are not as stark as first imagined. Despite a long and closely mirrored history of post-colonial loyal commitment to the wars of empire, shaped by cultural and political allegiance, Canada appeared to dissent, asserting a

\footnotetext{
${ }^{5}$ Henry Reynolds, Forgotten War, (Sydney: New South Books, 2013), 18.

${ }^{6}$ Christina Twomey, "The National Service Scheme: Citizenship and the Tradition of Compulsory Military Service in 1960s Australia," Australian Journal of Politics and History 58, no. 1 (2012): 67-81.
} 
path of nationalist independence. This article, therefore, documents the significance of this era in both countries' development of a new nationalist sentiment, breaking in their own ways from their inextricable ties to imperialist connection. It does so by drawing on the secondary literature to analyse aspects of the inter-related ideas of nationalism and war resistance in both countries' histories which help to contextualise newspaper reporting of protest and war politics as well as other primary sources noted to illustrate these patterns. The first section examines the emergence of a 'new nationalism', arguing that it occurred tentatively, almost reluctantly, throughout the long years of war in concert with the gradual questioning of the legitimacy of this specific war, and not necessarily war in general. This is followed by an analysis of the forms of dissent people assumed in protest of this particular war, comparing draft dodgers, resisters, and conscientious objectors in the two countries' experience of war resistance.

\section{The Nationalist Politics of War and its Resistance}

As Ann Mari Jordens observes, the anti-war sentiment in Australia was initially expressed not by the young, radical, hippies synonymous with the era, but by those old enough to have personally experienced the horrors wrought by wars of earlier decades:

Despite popular mythology, which portrays the Vietnam protest movement in terms of flowerbedecked, long-haired student radicals in colourful hippy clothes demonstrating in the streets, the protest movement, at least in its early stages, was overwhelmingly dominated by the middle-aged - that section of Australian society whose values and attitudes towards war had been formed by the experiences of the $1939-45$ war as young adults. ${ }^{7}$

\footnotetext{
${ }^{7}$ Ann Mari Jordens, "Conscription and Dissent: The Genesis of Anti-War Protest," in Vietnam Remembered, ed. Greg Pemberton (Sydney: Lansdowne, 2000), 74.
} 
The first public protests against the war organised in Australia occurred on the anniversary of Hiroshima Day, 9 August 1964, when approximately 2000 people marched in Sydney. ${ }^{8}$ In 1964, protestors were disallowed from carrying placards on poles, marching down a public street or standing still in any place for too long. Indeed, for most of the war, the democratic expression of resistance to it was significantly curtailed by conservative laws and social conventions actively banning public displays of activism and protest. As Nick Irving argues, the evolution of the anti-war movement in Australia during the Vietnam War years is fundamentally about participatory democracy arising out of a deeply conservative society. ${ }^{9}$ In a matter of only a few short years, Australian society appeared to emerge out of its rigid sociopolitical conservatism, achieving a social transformation that had, in reality, taken perhaps a century of progressive agitation to foment. Indeed, Australian society was changing, acting as a catalyst to anti-war sentiment, not necessarily the other way around.

Simply, while anti-war protest happened from the beginning of the war, active, concerted and popular war resistance did not occur until the final years of a very long war. And while Canada, as a nation, resisted participation in the war, choosing instead to believe in the efficacy of diplomacy and rolling peace talks, Australia's commitment to war was staunch, swift, and unwavering early on. The position of non-participation allowed Canadians to assume the moral high ground on sociopolitical terrain that became increasingly ethically unstable. Pearson was able to assert a new form of Canadian sovereignty, one that prided itself on being peaceful and reasonable, fertile ground for a self-portrayal as the world's peacekeeper.

\footnotetext{
${ }^{8}$ Bob Scates, unpublished manuscript, 1961-1989 held in the special collection of the Alfred Deakin Prime Ministerial Library, Deakin University, Victoria, Australia.

${ }^{9}$ Nick Irving, "Vietnam War Moratorium: participatory democracy," Drum, ABC, 29 September 2010, http://www.abc.net.au/news/2010-05-07/33984.
} 
Trudeau continued this tradition into the 1970 s, becoming popularly remembered as the Canadian prime minister most reluctant to support the military and bolster military spending during his premiership. ${ }^{10}$ As Gregory Brown argues, Trudeau continued the Pearsonian tradition of peacekeeping as the national agenda, describing the Canadian objective as one of 'helpful fixer' of international problems throughout his political career.${ }^{11}$ While sceptical of the efficacy of peacekeeping, Trudeau essentially bowed to popular Canadian sentiment that had embraced the concept wholeheartedly by the 1970 s as something truly Canadian in nature and something all Canadians could be proud of giving to the world.

For Australia, a similar 'new nationalism' developed out of this era, though it took a bit longer to assert itself into the mainstream consciousness. Australia, for most of the war, remained under the long reign of conservative leadership of successive Liberal Party governments. By 1972 when Gough Whitlam was elected the country's Labor prime minister, conservative (coalition Liberal and Country Party) governments had ruled the country for twenty-three consecutive years. By the early 1970s as the Vietnam War Moratorium marches surged in numbers and grabbed the public's attention, support for the once reverently observed Anzac Day had dwindled..$^{12}$ War, as a national activity, was, as Australians say, on the nose. This was a significant shift in public opinion about war. Only a few years earlier, in 1966, Prime Minister Harold Holt proclaimed that Australia would go 'all the way with LBJ'

\footnotetext{
${ }^{10}$ McKay and Swift, Warrior Nation

${ }^{11}$ Gregory Paul Brown, Canadian Peacekeeping during the Trudeau Years: A continuation of the "helpful fixer" tradition, Unpublished MA thesis, (McMaster University 1981), http://macsphere.mcmaster.ca/bitstream/11375/9984/1/fulltext.pdf.

${ }_{12}$ Christina Twomey, "Trauma and the reinvigoration of Anzac," History Australia 10, no. 3 (2013): 85 108.
} 
upon the occasion of American President Lyndon B. Johnson's visit to Australia and had comfortably won a federal election largely fought on supporting the war. ${ }^{13}$

As the war dragged on, the mainstream media in both countries represented antiwar protesters increasingly favourably. Jeffrey Grey argues that the antiwar protest movement of this era was 'remarkable for the ways in which it brought together various strands of socio-political thought and behaviour in a manner not seen since the First World War.' ${ }^{14}$ Similarly in Canada, as Jessica Squires contends, this period represents something significant in the progressive realignment of social and political priorities in Canada:

If the late 1960s were a period of readjustment of the hegemonic order, the anti-draft movement in Canada was in the thick of it...In the midst of this global political landscape, Canadian discussions about nationalism, culture, Quebec, and the American war on Vietnam percolated in complex ways among the general public and in the halls of government. Canadian support for American war resisters in the Vietnam War era was similarly complex. ${ }^{15}$

Declaring a new era of openness, progressive social values and truly democratic society, ${ }^{16}$ Gough Whitlam came to power as Australia's $21^{\text {st }}$ Prime Minister on 5 December 1972. His first act was to abolish conscription in the country. While not introduced specifically for the war in Vietnam, the draft had become increasingly unpopular. The day after being elected, Whitlam directed the Governor General to pardon draft resisters who had been imprisoned for their conscientious objection to the war. A great believer in the authority of the United Nations, Whitlam's faith in the organisation's efficacy had been punctured somewhat by the conflict in Vietnam. As

\footnotetext{
${ }^{13}$ Department of Veterans' Affairs, Australian Government, "Australia and the Vietnam War," http://vietnam-war.commemoration.gov.au/all-the-way-with-lbj/ ${ }^{14}$ Jeffrey Grey, "Protest and Dissent: Anti-Vietnam War Activism in Australia," in Australia's Vietnam War, eds. J. Doyle, J. Grey, and P. Pierce (College Station, Texas A\&M University Press 2002), 55. 15 Jessica Squires, Building Sanctuary: The movement to support war resisters in Canada, 1965-73, (Vancouver: UBC Press 2013) 19.

16 “'Open Government' Ministers to see secret files," Canberra Times, 12 December 1972, 1.
} 
James Curran notes, Whitlam was adamant that the world powers should not use the conflict in South-East Asia as a 'testing ground for their rivalry. ${ }^{17}$

Over the course of Australia's involvement in the war, public opinion shifted. As the Canberra Times editorialised on 7 December 1972, '(s)uddenly draft resisters have become respectable.' This had not always been the case. Those who opposed the war, once popularly perceived as radical ne'er-do-wells, became politically and socially tolerable, if not respectable. Whitlam's election was widely perceived as a symbolic acceptance of a new era for Australian society, ushering in progressive social change after decades of conservative government. In Canada, a similar wave of new nationalist spirit gripped the country and its people. John Thompson and Stephen Randall note, the Canadian relationship with their United States of America (USA) ally, the new empire, soured:

Canadians discovered that it was much less fulfilling to be America's junior partner than it had been to be Britain's...Partnership with America offered the material benefits of selling armaments and automobiles to the United States; it brought the spiritual poverty of continued complicity in the U.S. war in Vietnam. A strident new Canadian nationalism demanded that Trudeau's government act to stop the "Americanization" of Canada. ${ }^{18}$

Still, however, Canadians on the far-left wing of their country's politics, advocated for further progressive change, implying that Canada was complicit in the war and Pearson was not doing enough to facilitate its end. Those most vocal in the anti-draft movement in Canada were also often those most keen to promote a new and vibrant 'Canadianization', as activists and intellectuals agitated to distance their country from what they saw as the increasingly pernicious reaches of American imperialism. ${ }^{19}$ While the long years of conservative government in Australia had seen Liberal Prime Minister Harold Holt commit Australia to war as America's ally, in Canada, Pearson

\footnotetext{
17 James Curran, The Power of Speech: Australian Prime Minsters Defining the National Language, (Carlton Melbourne University Press, 2004), 72.

${ }^{18}$ John Thompson \& Stephen J. Randall, Canada and the United States: Ambivalent Allies (4 ${ }^{\text {th }}$ Edition), (Athens, GA: University of Georgia Press, 2008) 228.

${ }^{19}$ Squires, Building Sanctuary, 165.
} 
was diplomatically ambivalent about the American war in Vietnam. While Pearson sympathised with the anti-communist crusade being waged by the Americans, he was not convinced that Vietnam represented a clear and present danger to the Western world. ${ }^{20}$ The politics surrounding the war defied clear-cut and consistent nationalist positions for both countries as the years dragged on. This is most notably evident in the protest movements that became increasingly synonymous with this era, though, as the next section of this article lays out, such easy symbolism is also not so clearly pinned down. This provides a comparative analysis of the overlaps and disjunctures of the forms of war resistance and permutations of war resisters, looking first at Australia's experience of conscription and conscientious objectors before examining Canada's draft dodgers and deserters.

\section{Conscription and Conscientious Objectors in Australia}

Popular historical memory depicts the experience of the Vietnam War as one of widespread anti-war protest. In many ways, and to many ends, for both Canada and Australia, their histories have been dominated by this image which is at once both powerfully unifying and terribly divisive. In recent years, Australian governments of both major political parties have condemned the absence of public compassion characteristic, they claimed, of members of the anti-war movement of this era. In 2011, Prime Minister Julia Gillard weighed into the militarised history of Australia to state that those who had bravely fought in Vietnam had received unfairly bad treatment upon their return home. ${ }^{21}$ While some of Gillard's Labor colleagues from the earlier era had been instrumental in being protest leaders against the war in

\footnotetext{
${ }^{20}$ Thompson and Randall, Ambivalent Allies, 215.

${ }^{21}$ Max Blenkin, 'Vietnam War changed Australia, Julia Gillard says', Australian, 18 August 2011, http://www.theaustralian.com.au/news/latest-news/fedvietnam-war-changed-australia-pm-says/storyfn3dxity-1226117451277?nk=136d902ac48b41763df47c1b55a48734
} 
Vietnam, by 2011 there was bipartisan agreement that it was war veterans and not anti-war protesters who deserved to be remembered. The politicised logic of this assertion implies that the memory of war and its practice must be maintained in complete distinction and isolation from war resistance and the memory of anti-war protest. War and war resistance are binary opposites, not two sides of the same socio-political coin. Instead of society considering these issues together and critically, they were viewed as artificial, limiting, separating war from peace and warring from acts of resistance to it.

During the war, the Australian Labor Party (ALP) took a strong and consistent stance against Australian participation. Jim Cairns, who would become Deputy Prime Minister to Whitlam in 1972, led much of the anti-war protest movement in the country, ${ }^{22}$ though relatively quickly war resistance became awkward for the ALP. Retrospectively, it is possible to perceive a degree of hesitancy about how this position should be considered. For instance, in 1983 Bob Hawke, concerned about the extent to which prominent ALP politicians had been involved in the anti-war movement during Vietnam would become common knowledge, denied access to the caucus records concerning the war to the official Vietnam War historian, Peter Edwards. ${ }^{23}$

The issue of conscription became a divisive focal point around the war. The controversial introduction of National Service from 1964 became unpopular and has dominated retrospective depictions of the sentiment of this time as a wholly contentious act, the anti-war movement drawing most of its support from people's objections to the imposition it placed on young men's lives. However, Twomey

\footnotetext{
${ }^{22}$ Paul Strangio, Keeper of the faith: a biography of Jim Cairns (Carlton, Melbourne University Press, 2002).

${ }^{23}$ Geoff Kitney, "Don't worry, Washington: We never opposed Vietnam," National Times, 16-22 September 1983, 3.
} 
explains that the biggest controversy for the years of the War about national service was not the compulsion for men to serve the state, but the right of the state to 'compel them to serve overseas'. ${ }^{24}$ Conscription forced all men eligible for service to register for the draft by their twentieth birthday. Those who wished to be exempt from the draft could apply under the National Service Act (1951-1968), for an "order of exemption from liability to render service on the ground of conscientious belief. ${ }^{25}$ Twomey argues that while some dissented, the majority obeyed and even actively supported the legislation. ${ }^{26}$ Indeed, in the life of the scheme, only fourteen people went to jail, refusing to obey a callup notice. Though, a much greater number, 'over 1,200 , were determined by a court to be conscientious objectors, but this was still a small proportion of the overall numbers. ${ }^{27}$

The law itself was complicated and convoluted. For instance, while penalties for 'advising non-compliance' with the Act existed, 'the burden of proving your claim for exemption' rested on the applicant and calling witnesses to attest to your character and beliefs was a necessary part of the process (National Service Act and Regulations 1965). Section 29A did allow for a conscientious belief to be defined as one which 'is or is not part of the doctrines of a religion.' This allowed, at least in theory, for people to resist the state's compulsion to war on various philosophical grounds. The issue of conscientious objection has, throughout history, been a politically, morally, and socially contentious one. As Tom Frame argues, by 1966 in Australia the issue had transgressed mere politics and become a moral question of some public - and private - debate. Could there and should there, Frame posits,

\footnotetext{
${ }^{24}$ Twomey, "National Service Scheme," 78.

${ }^{25}$ Federal Pacifist Council of Australia, Conscientious objection and National service act 1951-1965: what the law is, what your rights are, what your obligations are (Hawthorn East: Federal Pacifist Council of Australia, 1965).

${ }^{26}$ Twomey, "National Service Scheme."

27 Ibid., 68.
} 
have been a means of exempting people from military service 'on the grounds of individual conscience when the government was indifferent to individual conscience on all other matters?'28

While initially a majority supported the war, anti-conscription protest became increasingly public and vocal, expressed by those who opposed what they saw as an undemocratic imposition by the state on their freedom and their lives. As noted, the 1966 Australian federal election, fought mainly on the issue of the war, was a disaster for the ALP. ${ }^{29}$ The popular image of the large-scale anti-war marches that swamped the streets of Sydney and Melbourne in the later years is hardly representative of sentiment for the duration of the war. Even in the later years of the war, anti-war activism, contends Grey, was not the dominant position expressed by the mainstream of Australia. ${ }^{30}$ 'The large numbers who protested in the three big Moratorium campaigns of 1970-71,' he argues, 'tends to obscure the fact that even larger numbers of Australians did not participate. ${ }^{31}$ However, the large numbers of people who sought to so publicly exercise their democratic right to protest what became an unpopular war suggests that the war became an increasingly divisive national commitment.

\section{Conscientious Objectors}

In Australia, political division surrounded the war and witnessed its own grassroots movement take shape as opposition to the war grew. The ALP believed that the war

${ }^{28}$ Tom Frame, "Where have all the conscientious objectors gone?", New College Lectures, UNSW, Sydney, 4 September 2003,

http://www.newcollege.unsw.edu.au/downloads/File/multimedia/pdfs/6364d3f0f495b6ab9dcf8d3b5c6e 0b01.pdf

${ }^{29}$ Jeffrey Grey, "In every war but one? Myth, history and Vietnam," in Zombie Myths of Australian Military History, ed. Craig Stockings (Sydney: UNSW Press 2010), 201.

$30 \mathrm{lbid}$.

${ }^{31} \mathrm{lbid}$. 
was at best a messy affair, being waged for unclear reasons and misguided purposes. In Australian politics in the 1960s there was a notable left/right divide in terms of support for the war. By the end of the decade, the political climate shifted discernibly to the left who sought the repeal of the draft, as growing unease and fatigue became a more and more widespread social phenomenon. ${ }^{32}$ By 1969 , as opposition to the war mounted, the Age reported that eight Victorian Federal Labor politicians had signed a petition urging conscientious objectors to defy the National Service Act. ${ }^{33}$ The Australian Council of Trade Unions (ACTU) lobbied the government for the release of imprisoned draft resisters and in July of 1970 the Australian reported that twenty-four trade union leaders in South Australia 'strongly supported the State Premier, Don Dunstan, for his personal statement opposing national service'. ${ }^{34}$ In a 1966 pamphlet, the Victorian state branch of the Labor Party described the war as deeply divisive and disruptive to Australian society, its people, and political stability: ${ }^{35}$

\begin{abstract}
Few experiences in Australia's history have split the Australian people more significantly and disturbed the organised Labor movement more deeply than the war in Vietnam and the completely merged and indivisible issues of conscription of twenty-year-old for service in the war. The Liberal Party Government, with the active support of the DLP ${ }^{36}$, has committed Australia to the cause of the Saigon Government, Australia has already sent 1500 men to Vietnam and the number is in the process of being trebled. Why did the Government send them there? What is the war all about? Is it a war against communism? Is it interference in the internal affairs of Vietnam? Why is the Labor Party so strongly opposed to Australia's participation? These are all questions that are dividing Australia. ${ }^{37}$
\end{abstract}

Something of a cultural paradigm shift occurred in the Western world in the decades of the Cold War. A social and political consciousness arose amongst a

\footnotetext{
${ }^{32}$ Alan Bloomfield and Kim Richard Nossal, "End of an Era? Anti-Americanism in the Australian Labor Party," Australian Journal of Politics and History 56, no. 4 (2010): 598.

33 "Objector gets 7 days' gaol," Age, 11 October 1969.

34 "Unions praise Dunstan's anti-draft statement," Australian, 4 July 1970, 1.

${ }^{35}$ Australian Labor Party (Victoria Branch), "Fact and Vietnam: On the war without a front line," 13 January 1966.

${ }^{36}$ A new party from the right-wing of the ALP that split from the party.

${ }^{37}$ Australian Labor Party (Victoria Branch), "Fact and Vietnam".
} 
significant proportion of the populations of Canada and Australia, locating cultural shifts in demographics rather than in the war itself. This shift is associated with the emergence of the new left movement, a generation of young people born into the relative prosperity of the baby boom and more likely to challenge authority and question societal norms. By the late 1960s, the war in Vietnam had been dragging on for most of that decade and as the death toll continued to rise, many Australians became increasingly agitated about it, angered by an apathy and ambivalence characterising the government's continued support for the war. Committed activist, Bob Scates, observed the change in his personal writings at the time:

For the broader peace movement, draft resistance campaigns provided a baptism in the practice and efficacy of direct action and civil disobedience. Hundreds of thousands of Australians from all social backgrounds succeeded in shaking off the incubus of fear and self-interest which had contained and vitiated dissent throughout the fifties and sixties. ${ }^{38}$

Though the numbers of Australian men who spent time in prison for their crime of resisting the draft and failing to serve in a war that they did not believe in was not huge, the stories of individuals who asserted their conscientious objection were well documented in the press. The media coverage was generally neutral or sympathetic to those who sought to exercise their consciences and represented a divisive and complicated issue, with laws not keeping up, or indeed directly contradicting, public sentiment. The reporting of the case of conscientious objector Denis O'Donnell illustrates this media ambivalence. Headlines such as 'Objectors provoked to defy NS law: claim,'39 'Army breaking objectors,' 'Prison letters indict Army barbarity'40 imply a sympathy for the objectors' position. Jim Cairns, prominent anti-war activist and Labor MP, publicly supported O'Donnell is his quest for legitimation of his beliefs. The

\footnotetext{
${ }^{38}$ Bob Scates, unpublished manuscript, 1961-1989 held in the special collection of the Alfred Deakin Prime Ministerial Library, Deakin University, Victoria, Australia.

${ }^{39}$ Age, 4 June 1968.

${ }^{40}$ Age, 10 June 1968.
} 
Australian reported that Cairns had advised the young man, assisting him because of his own personal and political belief that Australia should not be participating in the war that 'was not justified either in our own interests, or the people of Vietnam.'41

The case of Melbourne journalist Bruce Palling illustrated the heavily bureaucratic nature of a law out of touch with the interests and opinions of society. Palling had repeatedly been brought before the court for his failure to register for National Service. He refused to pay the fines issued by the court because, he stated, he did not believe in Australia's involvement in the war and that if he registered, he would be complicit in an unjust war. ${ }^{42}$ When he reported to police eleven months after being sentenced by the court for failing to register for service, he was told he would serve jail time, but he was sent away, being told that he was not their responsibility as his crime was a federal matter. The article depicts the authorities and the federal government as ineffectual and incompetent; the implication was that the law was impractical and illogical.

The story of Laurie Carmichael's case similarly represents an out-of-touch government and a legal system hamstrung by old-fashioned laws. On 11 October 1969 the Age reported that Magistrate Kelly decided against Carmichael, finding that while he no doubt held his anti-war beliefs, 'others hold equally conscientious beliefs' and that because he had broken the law, 'I am bound to penalise you for it. ${ }^{43}$ Directly underneath this story, the paper reported on the views of the Carmichael's father with a story headed, 'Law is hopeless: Carmichael snr.'44

\footnotetext{
${ }^{41} \mathrm{Jim}$ Cairns quoted in "Cairns tells court he advised unwilling conscript," Australian, 14 November 1967, 2.

${ }^{42}$ Darmody, "Red tape weapons in war of nerves," Age, 12 August 1970.

43 "Objector gets 7 days' gaol," Age, 11 October 1969.

44 "Law is hopeless: Carmichael Snr.," Age, 11 October 1969.
} 
David Monaghan was a twenty-one-year-old university student who successfully appealed for exemption from participation in the war based on his strong moral conviction that 'Western countries should not be involved there. ${ }^{45} \mathrm{He}$ was the first Australian who succeeded in achieving exemption from a specific war, rather than to war in general, on the grounds of his conscientious objection. The dilemma for Australia posed by the consciences of young men, not yet old enough to vote but compelled into military service in an increasingly unpopular and controversial war, was not being adequately addressed by courts with power to decide if someone's convictions were sincere. Class and other social factors mitigated the success of those who sought exemption on the grounds of their conscience. As Jordens argues, 'it was easier for a magistrate to understand an articulate applicant for conscientious objector status, who was able to demonstrate his point from a wide range of religious or historical reading, and who had the support of an older person, preferably a lawyer.'46

Bruce Grant argued in the Australian in June 1967 that the government persisted in its claim to legitimise conscientious objection despite evident philosophical limitations with the system:

I think it is generally accepted that it is not for the courts to determine whether this objection is cogent, reasonable, right or wrong, but whether if raised, it is conscientious, whether the convictions on which it is based are conscientiously held. What, then, are the courts to do with conscientious objectors to the Vietnam War? Once they become servicemen the particularity of their objection can no longer be expressed as a principle, unless they are prepared to be imprisoned and possibly dishonourably discharged. It is no real answer to say that, in fact, in the services are not interested in taking recalcitrants or worriers to Vietnam. Maybe, maybe not. Much depends on the circumstances, even on personalities. ${ }^{47}$

Tony Dalton was a twenty-year-old Melbourne man who refused to be drafted. He was sentenced to seven days in jail for failing to attend a National Service medical examination. The magistrate also fined his father, Leslie Dalton, ten dollars for

\footnotetext{
45 "Anti-Vietnam youth exempted from call-up," Australian, 30 June 1967, p. 1

${ }^{46}$ Jordens, "Conscription and Dissent," 70.

${ }^{47}$ Bruce Grant, "Vietnam objectors," Australian, 30 June 1967, 5.
} 
contempt of court after he declared that he had 'nothing but contempt' for the sentencing judge ${ }^{48}$ Dalton senior made a statement condemning war. 'War', he said, 'only brings destruction and suffering. It does not create, and modern methods have made war more evil than before. ${ }^{49} \mathrm{He}$ described his objections to the war as being based on 'moral law'. 50

Barry Johnston was a twenty-two-year-old primary school teacher who did not want to go to war in Vietnam. In February 1972 he absconded, fleeing from his West Brunswick Primary School employer to hide from the authorities..$^{51}$ In the 1972 election, he became an ALP candidate for the federal seat of Hotham in Melbourne.

Controversy ensued, however, when Whitlam appealed to Johnston to surrender himself to federal police. The Melbourne daily broadsheet, the Age, reported that the 'underground draft resister who has been asked by the Labor leader to give himself up, met reporters yesterday to repeat his defiance of Mr. Whitlam. ${ }^{52}$ Whitlam had come under pressure from the media, the opposition, and members of his own party for his stance on draft resisters. Whitlam had stated that dodging the draft was not a crime, and that it was too dramatic to suggest that Johnston had committed a crime worthy of jailing. On 3 March 1972, the Sun quoted Whitlam as saying, 'the public does not regard breaches of laws of this character - statutory offences - in the same way it regards crimes against the person or property. ${ }^{53}$ The national broadsheet, the Australian, reported that a meeting of the national executive of the ALP issued an open

\footnotetext{
48 "Police seize NS father," Herald, 17 October 1969.

49 "Police seize NS father".

50 "Whole system needs change," Age, 7 May 1970, p. 1

51 "Anti-draft candidate stays out", Age, 9 September 1972, p. unknown

52 Kevin Childs, "Draft resister defies Whitlam", Age, 4 July 1972, p. unknown

53 Gough Whitlam as quoted by the Sun, 3 March 1972, p. 1
} 
letter calling for an end to 'the threats of arrest, prosecution and imprisonment of all draft resisters. ${ }^{54}$

The Australian Vietnam War Moratorium movement was built on the foundations of the Cold War peace movement. As John Murphy points out, the movement was timely and efficient, seizing upon a growing public doubt in their government's consistent support for war:

Initiated in late October 1969 and culminating in May the following year, the Moratorium campaign's rapid growth suggested it was not only timely, but an essential development of the political realignments of the previous years...After the protracted slump of 1968 and 1969, the peace movement had mobilised precisely the coalition of forces to which it had always aspired. ${ }^{55}$

The popularity of the Moratorium Movement in major cities across Australia challenged the existing social order. In South Australia, the Vietnam War Moratorium protest disrupted Adelaide and its civil society to such an extent that the State Government dedicated a Royal Commission to investigate its causes and impact. ${ }^{56}$ Ostensibly this inquiry was concerned with improving traffic related obstruction, and resultant disruptions to the good order of Adelaide society. The implicit message of the Royal Commission hinted at an anxiety about radical politics and its public expression. Jordens points out that despite the cultural and political significance of the moratorium movement in 1970s Australia, it is necessary to temper the historical mythology:

In most societies, only a small minority of the population are politically active, organised, interested and well-informed. The great majority are none of these things, especially on matters of international affairs. In many cases where a government policy does not immediately affect or interest that majority it will support passively, or defer to, the government as the legitimate authority. ${ }^{57}$

The understanding of cultural relativity of radical political movements away from the normative centre, helps to make sense also of the Canadian experience of this era

\footnotetext{
54 "Greenwood hits at resister", Australian, 6 July 1972, p. unknown

55 John Murphy, Harvest of Fear: A history of Australia's Vietnam War (St. Leonards, NSW: Allen \& Unwin, 1993), 241.

${ }^{56}$ Charles Hart Bright for the House of Assembly, South Australia, Royal Commission Report: September Moratorium Demonstration (Adelaide: Government Printer, 1971).

57 Jordens, "Conscription and Dissent," 72.
} 
into which American draft dodgers and resisters sought asylum from an

unconscionable war and, for some, an intolerable society.

\section{Canada - Safe Haven for Draft Dodgers and Deserters?}

Unlike Australians protesting conscription as a symbolic unifier of growing anti-war sentiment, Canadians experienced the war less directly. Instead of fighting against communism, the country offered itself up as a site of refuge for those fleeing from its practice, quietly accepting Americans seeking safe haven from their own country's war mongering. Exact figures of those who migrated north are contested and difficult to accurately assess. Valerie Knowles suggests that from 1965 until the war's end, approximately thirty to forty thousand Americans of draft age entered Canada:

Whether or not this estimate is accurate, the fact remains that immigration from the United States was high as long as the war raged and that in 1971 and 1972 Canada received more immigrants from the United States than from any other country. Although some of these transplanted Americans returned home after the Vietnam War, most of them put down roots in Canada, making up the largest, best-educated group this country had ever received. ${ }^{58}$

Canada made this protest against American imperialism steadily, silently accepting

young Americans who drove across the border and into a country that was not at

war. Brian Bow (2008) articulates the significance of this cultural shift as being about Canadians demonstrating a creeping disdain for their southern neighbours' imperialism:

The war in Vietnam was the first major Cold War crisis in which Canada chose to stand apart from the United States, and this affected not only Canadian diplomats' capacity to influence U.S. decisions, but also the Canadian public's perceptions of what the war said about American values and priorities. Canadian government officials generally stuck with the established practice of "quiet diplomacy," but the opposition parties, the media, and others attempted to influence their own government, and perhaps also the United States, by vigorously criticizing not only the war, but also American society more generally. ${ }^{59}$

\footnotetext{
${ }^{58}$ Valerie Knowles, Forging Our Legacy: Canadian Citizenship and Immigration, 1900-1977 (Public Works and Government Services Canada 2000), http://www.cic.gc.ca/english/resources/publications/legacy/chap-6a.asp\#chap6-14 59 Brian Bow, "Anti-Americanism in Canada Before and After Iraq," American Review of Canadian Studies 38, no. 3 (2008), 347.
} 
The act of providing those displaced by the war with a site of refuge was a powerful symbolic gesture of protest, resisting the open aggression of the American war. Such an act was consistent with Canada's determination in this era to play the part of the world's peaceful diplomat. This image played a persuasive role in shaping the national Canadian consciousness, especially for those keen to represent themselves as culturally and politically divergent from their American neighbours. However, as Squires argues, the extent of the draft resisters movement in Canada was more a result of a concerted grassroots social enterprise than of official government policy:

In general, the draft dodgers' phenomenon is one of the events to which Canadians often point, uncritically, to emphasize the difference between Canadians and Americans. But the idea of Canada as a peaceful nation is an oversimplification. The myth is that Canada, a more peaceable country than the United States, allowed American draft dodgers and deserters to find refuge from militarism across the border, which, while true, over-looks how that refuge was achieved - through the efforts of a social movement. ${ }^{60}$

Activism operated at a localised, grassroots level in Canada, as various groups converged to assist Americans to escape from the war. Though successive Liberal Canadian Prime Ministers Pearson and Trudeau publicly resolved not to commit the country militarily to the war in Indo-China, and while many Canadians were supportive of this decision that was seen as a timely assertion of sovereignty, the acceptance of Americans escaping from their own country's all-out commitment to the same war was not necessarily widely popular. As Thompson and Randall describe, the era saw a turnaround in the net migration numbers crossing the USA/Canadian border. ${ }^{61}$ According to a poll taken of Canadians' opinions in 1968, half of the respondents wished the American draft dodgers would stop coming. This was 'more a negative comment about the United States than a statement of support for the Vietnam War.' 62 While the war wasn't popular with Canadians, neither, it

\footnotetext{
${ }^{60}$ Squires, Building Sanctuary, 2.

61 Thompson and Randall, Ambivalent Allies, 230.

$62 \mathrm{lbid}$.
} 
seemed, were those fleeing from their warring neighbour, despite a shared opposition to the war.

Academic and popular debate in recent years has focussed on ascertaining the veracity of an infamous Trudeau quote, apparently boldly stating that those fleeing the American military were most welcome in his Canada. Joseph Jones argues that a curious revisionism has wrongly credited Trudeau with opening the gates to Canada and extending a fond and unlimited welcome to all who sought to escape from the American military during the Vietnam War era:

It has been assumed that specific and intentional action opened the gates to Canada for U. S.
Vietnam War resisters. Since Trudeau was Canada's political leader at the time, it has been
further assumed that he was the agent, and even that he made a declaration and broadcast a
welcome. This kind of thinking is as folkloric as the products which perpetuate it - the image
of opening the gates, and a text bite with a Trudeau logo... Unwarranted assertions of national
prescience or essential humanitarianism do injustice not only to Canada but to truth and
history. ${ }^{63}$ While he might not have actively promoted Canada as a safe-haven for war resisters of any sort, Trudeau was at least agreeable to draft dodgers entering the country on his watch. At a National Press Club meeting in Washington, DC in 1969, he referred to them as high-quality immigrants who were welcome to join Canadian society. ${ }^{64}$ Canadians, Trudeau stated, were also sympathetic to these evaders of the war. There was, however, a very important distinction made between those who were dodging - avoiding - the draft and those who had deserted the army. ${ }^{65}$ Dodgers were fine, and generally of a higher social class, while the latter were much less desirable, often poorly educated, and low-skilled, and seen as difficult to assimilate into middle-class Canadian society.

\footnotetext{
63 Joseph Jones, Happenstance and Misquotation: Canadian Immigration Policy 1966-1974, the Arrival of U.S. Vietnam War Resisters, and the Views of Pierre Trudeau (Vancouver: Quarter Sheaf 2008), 9.

${ }^{64}$ Luke Stewart, "The re-writing of history: The misuse of the draft 'dodger' myth against Iraq war resisters in Canada," History Matters, http://activehistory.ca/papers/history-papers-12/.

${ }^{65}$ Stewart, "The re-writing of history".
} 
Left-wing activists and peace advocates were far from satisfied with the official Canadian response to the war in Vietnam, perceiving the government to be meek and acquiescent to American imperial might. In 1966 Farley Mowat, Canadian writer and veteran of the Second World War, spoke out about what he described as the weak and complicit formal position taken by the government:

I say this to Canadians. If we are a nation; if we are people who place any value on ethics and morality, then we must take an unequivocal stand against the actions of the United States in Vietnam. Our Government will not act for us, since it is demonstrably subject to the will of the United States. We must therefore act individually and declare publicly and privately, in any and all company, as frequently as possible, despite reprisals and the dangers of reprisals, that the United States is guilty of a great crime against mankind. ${ }^{66}$

Despite Canada's official refusal to contribute militarily to the war against Vietnam, the left argued that it was complicit in the killing going on. This was a significant attack on the actions and beliefs of the Liberal Government headed by Pearson, the man who put Canada on the world map in 1957 by being awarded the highest honour in international diplomacy, the Nobel Peace Prize. Where, the left asked from Toronto in 1966, was this global advocate and activist for peace, and what was he doing to stop the war?

\section{Dodgers - the good war resisters}

Similar factors contributed to the realisation of many American men who had been drafted into the army during the war in Vietnam that war was a brutal and brutalising experience causing many to flee north across the border and into Canada. As one draft dodger explained to Kasinsky in a rare anthropological study conducted at the time of those seeking refuge, the war was unconscionable and, therefore, fleeing across the border to Canada was his only ethical option: 'I vehemently object to this

\footnotetext{
${ }^{66}$ Farley Mowat, Farley Mowat speaks out on Canada's role in Vietnam, published pamphlet from the proceedings of the Conference of Canada's Role in Vietnam (Toronto 1966), 12.
} 
war. It's a barbarous war... if there is such a thing as right and wrong, this is as black and white as anything could possibly be. ${ }^{167}$

The draft dodgers interviewed by Kasinsky commonly used terms such as 'inhumane' and 'intolerable' to describe their experience of military training and war. ${ }^{68}$ Kasinsky thought that for Canadians themselves, the willingness to accept the American refugees fleeing from a war in which they were not active participants was symbolic of a changing relationship with the USA. Bearing witness to the televisual horror of the war and the human ugliness of race riots across America, Canadians became 'less enamoured of the American way of life and began to question their own desire to emulate the United States. ${ }^{\cdot 69}$ Marshall McLuhan and Quentin Fiore pronounced that the Vietnam War was Canada's first TV star. ${ }^{70}$ However, it took a long and bloody decade of jungle battle, and the televising of war to become commonplace, for those sitting in their lounge rooms to turn against it in significant numbers. By the middle of the protracted period of the Vietnam War, as McLuhan argued in his seminal 1967 text, never before had the power of the mass media infiltrated so much of society. 'The living room,' he suggested, 'has become a voting booth,' in which the inter-play of war and politics were being forever altered. ${ }^{71}$ When the reality of war became visible to people, their support diminished.

Canada's upsurge in nationalism in the 1960s, was partly a result of a growing awareness of the extent of the domination of, and reliance on, American industry in the Canadian economy. American companies controlled significant percentages of all

\footnotetext{
${ }^{67}$ Renee Kasinsky, Refugees from Militarism: Draft-Age Americans in Canada (New Brunswick, NJ: Transaction Books, 1976), 33.

${ }^{68}$ Kasinsky, Refugees from Militarism.

69 Ibid., 56.

${ }^{70}$ Marshall McLuhan and Quentin Fiore, The Media is the Message (Ringwood, Vic.: Penguin Books: 1967).

71 Ibid.
} 
Canadian big industries. Indeed, as Berton documents, by 1967, 'no other Western nation had given up so much of its economic control' as had Canada. ${ }^{72}$ As Kasinsky argues, the 'rise of Canadian nationalism in turn resulted in political ambivalence toward the United States'. ${ }^{73}$ By the end of the 1960s, Canada, where 'peace and prosperity reigned,' began to enjoy a renaissance of nationalism. ${ }^{74}$

For the men who fled to Canada to avoid participating in the war in Vietnam, many did so with a newly radicalised consciousness. Conversely, most were not radical in their political outlook, or, indeed, politicised at all and only wanted to avoid going to war. For those whose consciousness had been raised to a state of harsh criticism of the American military-industrial complex, they were, as one pamphlet helping to disseminate information to prospective draft dodgers, seeking an 'Escape from Freedom' ${ }^{75}$ The need to make a political statement was a (counter) cultural imperative. As one draft dodger explained, while he could have registered as a conscientious objector, doing so would mean he was still complicit, a cog in the American war machine. 'The only thing I would not be doing,' he argued, 'was pulling a trigger. ${ }^{, 76}$ Kasinsky describes the sense of anger that many of the draft dodgers felt at the betrayal of the very American democratic values they had been brought up to believe in. Most of these men were patriotic Americans. Those who were most disillusioned with their country were those who had believed most fervently in the American Dream. What they saw as the disintegration of their society was most sharply evidenced by the continued pursuit of the unjust war:

As educated Americans they aspired to professional careers. They felt it was very unfair and un-American to be forced to interrupt their personal careers to serve in a military that was conducting a war they felt to be illegal and, above all, immoral. They objected to the undemocratic use of the draft and they were happy to find a country of refuge that did not

\footnotetext{
72 Pierre Berton, 1967: The Last Good Year (Toronto: Doubleday, 1997), 59.

73 Kasinsky, Refugees from Militarism, 57.

${ }^{74}$ Berton, The Last Good Year, 17.

75 Ibid., 198.

76 Ibid.
} 
compel them to take part in the military. They were not anxious to leave their country, yet there was no alternative. Many had tried playing the game and following the rules; still there was no reconciliation. ${ }^{77}$

As in Australia, the issue of social class pivotal in the circumstances surrounding the experience of those who sought refuge from the war in Vietnam. One American draft dodger, exiled from his life running an art gallery in San Francisco, explained his anger at having his life turned upside down in a leaflet distributed by the Canadian organisation, the Committee to Aid American War Objectors (196-): 'I have a thing about the idea that at a certain age you are taken out of a civilized life and turned into a machine that has no choice and whose only job is to take away life...I was making a decent living. But I looked it over and I had to get out.. ${ }^{78}$

It was, as Berton explains, the 'affluent and the best-educated whites who crossed the border, ${ }^{79}$ in large part the result of Canadian immigration rules favouring immigrants who had the best prospects of finding employment in their new country. In general, however, while most draft dodgers were of the American middle-class, the deserters were mostly of a lower social class and often comparatively uneducated. ${ }^{80}$ Deserters were most likely working-class, with little or no formal education or training and alienated from their families and support networks at home. These difficulties were compounded by a negative public perception of desertion not improved by the fact that some were deported from Canada for having broken the law in myriad, mostly petty ways. ${ }^{81}$ The government introduced a point system for immigration, designed to ameliorate any subjective assessment by zealous bureaucrats. The Canadian government welcomed the draft-dodging refugees almost without exception. Indeed,

\footnotetext{
${ }^{77}$ Kasinsky, Refugees from Militarism, 150.

${ }^{78}$ American draft dodger, Norm Rich, as quoted in a leaflet, entitled "Why they Chose Canada", produced by the Committee to Aid American War Objectors, 196-, McMaster University Special Collection, http://digitalcollections.mcmaster.ca/committee-aid-american-war-objectors-leaflet-196.

${ }^{79}$ Berton, The Last Good Year, 201.

${ }^{80}$ Kasinsky, Refugees from Militarism, 171.

${ }^{81}$ Squires, Building Sanctuary.
} 
many immigration officials let applicants into the country whose application fell short of reaching the required points when they discovered the applicant was a war resister. ${ }^{82}$ Universities played a major part in the anti-war movement in both Canada and Australia. In Canada, they were often the points of information sharing and support to draft dodgers, providing a practically focused, integral component of the anti-war movement. The Committee to Aid American War Objectors, for instance, was begun by a young mathematics professor in Vancouver and grew to have branches on university campuses in Montreal and Toronto, the Canadian cities most populated by the American draft dodgers. ${ }^{83}$

\section{$\underline{\text { Conclusion }}$}

Canada and Australia experienced the war in different ways, one country's citizens actively fighting in it on the ground in Vietnam, the other fighting against the cultural and political hegemony that the war represented. Australia was committed to the war, and its mythologies of war were challenged as part of the protest against war. However, the extent of that challenge should not be overstated. As for Canada, its withdrawal from war during this period was not absolute and it was in the process of developing a new self-image. The differences in their experiences of the war reflected the political regimes then in power as well as geographical realities: Australia in Asia and Canada as the close American neighbour. The differences between the two countries' experience of the war were not so wide as a simple comparison might suggest. Resistance to the war grew out of longer term social and demographic shifts, reflected in public sympathy for those who resisted war.

\footnotetext{
${ }^{82}$ Berton, The Last Good Year, 203.

${ }^{83}$ Ibid., 202.
} 
For both countries, those who openly and actively resisted and opposed this perceived cultural incursion would come to define their respective country's national mythologies of the Vietnam War. Canada was openly critical of the war and, though it did not commit itself militarily to participate in supporting the Americans' battle, Canadians did play diplomatic roles throughout the conflict in largely futile attempts to de-escalate the war and prevent the conflict from spreading further afield. ${ }^{84}$

The decade known as the nineteen-sixties (that has cultural continuity well into the 1970 s, defying mere temporal limitations) is weighty with popular cultural meaning. The media has long sought to depict this period in the history of the West as being a significant departure point from the conservatism of the post-war era in which vapid consumerism filled the lives of those grateful to forget about the world wars' years of collective hardship. War itself, I argue, was not necessarily unpopular in this period. However, the Vietnam War, very specifically, was by its end. This was not an unprecedented era of radical pacifist activism. Politics and cultural change did not dominate the lives of the majority of Australians and Canadians. However, there were some undeniable shifts in thinking that signify a strand of progressive evolution in western society. Pearson introduced many significant social policies that assisted Canada to develop into a modern social democracy. Similarly, Whitlam introduced radical social change in the few short years of his leadership of the country.

Ideas of peacekeeping and peace emerged in this period as important cultural symbols for both countries keen to move past the rolling decades of war of the twentieth century. While the Cold War persisted well into the proceeding decades, these concepts would grow in political strength as both countries devoted themselves to multilateralism and international diplomacy. The following decades, the 1980 s and

${ }^{84}$ Thompson and Randall, Ambivalent Allies, 215. 
early 1990s, within this cultural context, saw the political ascendency of peacekeeping emblematic of the 'new nationalism' for a post-cold war era of globalism.

\section{Bibliography}

Secondary sources

Berton, Pierre. 1967: The Last Good Year, Toronto: Doubleday, 1997.

Bloomfield, Alan \& Kim Richard Nossal. "End of an Era? Anti-Americanism in the Australian Labor Party". Australian Journal of Politics and History 56, no. 4 (2010): 592-611.

Bow, Brian. "Anti-Americanism in Canada Before and After Iraq". American Review of Canadian Studies 38, no. 3 (2008): 341-359.

https://doi.org/10.1080/02722010809481718

Brown, Gregory Paul. Canadian Peacekeeping during the Trudeau Years: A continuation of the "helpful fixer" tradition. Unpublished MA thesis, McMaster University, 1981, http://macsphere.mcmaster.ca/bitstream/11375/9984/1/fulltext.pdf (accessed 18 February 2015).

Curran, James. The Power of Speech: Australian Prime Minsters Defining the National Language, Carlton: Melbourne University Press. 2004.

Dapin, Mark. The Nashos' War: Australia's National Servicemen and Vietnam, Sydney: Penguin Books. 2014.

Frame, Tom 'Where have all the conscientious objectors gone?', New College Lectures, UNSW, Sydney, 4 September 2003, http://www.newcollege.unsw.edu.au/downloads/File/multimedia/pdfs/6364d3f0f495b 6ab9dcf8d3b5c6e0b01.pdf (accessed 12 October 2014)

Jordens, Ann Mari 'Conscription and Dissent: The Genesis of Anti-War Protest.' In Vietnam Remembered, edited by Greg Pemberton, 60-82. Lansdowne: Sydney. 2000.

Grey, Jeffrey. 'Protest and Dissent: Anti-Vietnam War Activism in Australia.' In Australia's Vietnam War, edited by J. Doyle, J. Grey, and P. Pierce, 55-63. College Station: Texas A\&M University Press, 2002.

Grey, Jeffrey 'In every war but one? Myth, history and Vietnam.' In Zombie Myths of Australian Military History, edited by Craig Stockings, 190-212. Sydney: UNSW Press. 2010. 
Irving, Nick 'Vietnam War Moratorium: participatory democracy', Drum, ABC, 29 September 2010, http://www.abc.net.au/news/2010-05-07/33984 (accessed 28 September 2014).

Jones, Joseph. Happenstance and Misquotation: Canadian Immigration Policy 19661974, the Arrival of U.S. Vietnam War Resisters, and the Views of Pierre Trudeau. Vancouver: Quarter Sheaf. 2008.

Kasinsky, Renee. Refugees from Militarism: Draft-Age Americans in Canada. New Brunswick, NJ: Transaction Books. 1976.

Knowles, Valerie (2000), Forging Our Legacy: Canadian Citizenship and Immigration, 1900-1977, Public Works and Government Services Canada, http://www.cic.gc.ca/english/resources/publications/legacy/chap-6a.asp\#chap6-14 (accessed 20 March 2015).

McKay, lan and Jamie Swift. Warrior Nation: Rebranding Canada in an Age of Anxiety. Toronto: Between the Lines. 2012.

McLuhan, Marshall and Quentin Fiore. The Media is the Message. Ringwood, Vic.: Penguin Books. 1967.

Mowat, Farley. Farley Mowat speaks out on Canada's role in Vietnam, published pamphlet from the proceedings of the Conference of Canada's Role in Vietnam. Toronto, 1966.

Murphy, John. Harvest of Fear: A history of Australia's Vietnam War. St. Leonards, NSW: Allen \& Unwin. 1993.

Reynolds, Henry. Forgotten War. Sydney: New South Books, 2013.

Scates, Bob. Unpublished manuscript, 1961-1989 held in the special collection of the Alfred Deakin Prime Ministerial Library, Deakin University, Victoria, Australia.

Stewart, Luke 'The re-writing of history: The misuse of the draft "dodger" myth against Iraq war resisters in Canada,' History Matters, http://activehistory.ca/papers/history-papers-12/ (accessed 9 October 2014).

Strangio, Paul. Keeper of the faith: a biography of Jim Cairns. Carlton, Vic.: Melbourne University Press, 2002.

Squires, Jessica. Building Sanctuary: The movement to support war resisters in Canada, 1965-73. Vancouver: UBC Press, 2013.

Thompson, John and Stephen J. Randall. Canada and the United States: Ambivalent Allies, $4^{\text {th }}$ Edition. Athens, GA: University of Georgia Press, 2008.

Torrance, Judy. Public Violence in Canada, 1867-1982. Montreal: McGill-Queen's Press, 1986. 
Twomey, Christina. "The National Service Scheme: Citizenship and the Tradition of Compulsory Military Service in 1960s Australia." Australian Journal of Politics and History 58, no. 1 (2012): 67-81. https://doi.org/10.1111/j.1467-8497.2012.01624.x

Twomey, Christina. "Trauma and the reinvigoration of Anzac." History Australia 10, no. 3 (2013): 85-108. https://doi.org/10.1080/14490854.2013.11668482

\section{Primary sources}

Australian Labor Party (Victoria Branch). 'Fact and Vietnam: On the war without a front line,' 13 January 1966.

Blenkin, Max 'Vietnam War changed Australia, Julia Gillard says', Australian, 18 August 2011. http://www.theaustralian.com.au/news/latest-news/fedvietnam-warchanged-australia-pm-says/story-fn3dxity1226117451277?nk=136d902ac48b41763df47c1b55a48734 (accessed 28 September 2014).

Charles Hart Bright for the House of Assembly, South Australia. Royal Commission Report: September Moratorium Demonstration. Adelaide: Government Printer, 1971.

Childs, Kevin. "Draft resister defies Whitlam.” Age, 4 July 1972.

Grant, Bruce. "Vietnam objectors.” Australian, 30 June 1967: 5.

Kitney, Geoff. "Don't worry, Washington: We never opposed Vietnam.” National Times, 16-22 September 1983: 3.

Department of Veterans' Affairs, Australian Government, 'Australia and the Vietnam War.' http://vietnam-war.commemoration.gov.au/all-the-way-with-lbj/ (accessed 16 October 2014).

'Trudeau opens door to draft dodgers.' CBC Digital Archives.

http://www.cbc.ca/archives/categories/war-conflict/vietnam-war/seeking-sanctuarydraft-dodgers/trudeau-opens-the-door-to-draft-dodgers.html (accessed 9 October 2014).

Federal Pacifist Council of Australia. Conscientious objection and National service act 1951-1965: what the law is, what your rights are, what your obligations are. Hawthorn East Vic.: Federal Pacifist Council of Australia, 1965.

“"Open Government” Ministers to see secret files." Canberra Times, 12 December 1972.

"Why they Chose Canada", produced by the Committee to Aid American War Objectors, 196-, McMaster University Special Collection.

http://digitalcollections.mcmaster.ca/committee-aid-american-war-objectors-leaflet196 (accessed 21 March 2015). 
"Greenwood hits at resister." Australian, 6 July 1972.

"Cairns tells court he advised unwilling conscript." Australian, 14 November 1967: 2. Age, 4 June 1968.

Age, 10 June 1968.

"Police seize NS father." Herald, 17 October 1969.

"Whole system needs change". Age, 7 May 1970: 1.

"Red tape weapons in war of nerves." Age, 12 August 1970.

"Anti-draft candidate stays out." Age, 9 September 1972.

Sun, 3 March 1972. 1. 